\title{
Comparison of RNA extraction methods from biofilm samples of Staphylococcus epidermidis
}

\author{
Angela França, Luís DR Melo and Nuno Cerca*
}

\begin{abstract}
Background: Microbial biofilms are communities of bacteria adhered to a surface and surrounded by an extracellular polymeric matrix. Biofilms have been associated with increased antibiotic resistance and tolerance to the immune system. Staphylococcus epidermidis is the major bacterial species found in biofilm-related infections on indwelling medical devices. Obtaining high quality mRNA from biofilms is crucial to validate the transcriptional measurements associated with the switching to the biofilm mode of growth. Therefore, we selected three commercially available RNA extraction kits with distinct characteristics, including those using silica membrane or organic extraction methods, and enzymatic or mechanical cell lysis, and evaluated the RNA quality obtained from two distinct $S$. epidermidis bacterial biofilms.

Results: RNA extracted using the different kits was evaluated for quantity, purity, integrity, and functionally. All kits were able to extract intact and functional total RNA from the biofilms generated from each S. epidermidis strain. The results demonstrated that the kit based on mechanical lysis and organic extraction (FastRNA ${ }^{\circledR}$ Pro Blue) was the only one that was able to isolate pure and large quantities of RNA. Normalized expression of the icaA virulence gene showed that RNA extracted with PureLink ${ }^{\mathrm{TM}}$ had a significant lower concentration of icaA mRNA transcripts than the other kits tested.

Conclusions: When working with complex samples, such as biofilms, that contain a high content extracellular polysaccharide and proteins, special care should be taken when selecting the appropriate RNA extraction system, in order to obtain accurate, reproducible, and biologically significant results. Among the RNA extraction kits tested, FastRNA ${ }^{\circledR}$ Pro Blue was the best option for both S. epidermidis biofilms used.
\end{abstract}

\section{Background}

Staphylococcus epidermidis, a normal inhabitant of normal human skin and mucosa, has recently emerged as a leading cause of biofilm-related infections, particularly, in patients with indwelling medical devices [1,2] due to its ability to adhere to abiotic surfaces and to form biofilms $[2,3]$. The quantification of specific messenger RNA (mRNA) from these biofilms is crucial to understanding the molecular mechanisms behind biofilm formation and maturation on the surface of medical devices. The success of any RNA-based analysis depends on the yield, purity, and integrity of the RNA [4,5]. However, different RNA extraction methods can yield RNA with varying levels of quality [6,7]. Currently, there

\footnotetext{
*Correspondence: nunocerca@ceb.uminho.pt
IBB-Institute for Biotechnology and Bioengineering, Centre of Biological
Engineering, University of Minho, Campus de Gualtar, 4710-057 Braga, * Correspondence: nunocerca@ceb.uminho.pt
IBB-Institute for Biotechnology and Bioengineering, Centre of Biological
Engineering, University of Minho, Campus de Gualtar, 4710-057 Braga,

* Correspondence: nunocerca@ceb.uminho.pt
IBB-Institute for Biotechnology and Bioengineering, Centre of Biological
Engineering, University of Minho, Campus de Gualtar, 4710-057 Braga, Portugal
} Portugal

are numerous methods for RNA extraction available, however there are only a few published studies comparing RNA extraction from biofilm samples [8-10]. Biofilm samples pose an increased problem to RNA extraction procedure mainly due to the presence of the extracellular matrix, which is estimated to comprise about $90 \%$ of the total biofilm biomass [11]. Polysaccharides, the major component of the S. epidermidis biofilm matrix, seems to interfere with RNA extraction methods making bacterial cell lysis and nucleic acid purification difficult, and the purified RNA may still contain inhibitory substances [12,13]. Therefore, in this study we compared three different commercially available RNA extraction kits to determine their ability to obtain high quantity, pure, intact, and functional RNA from S. epidermidis biofilms. The selected kits were based on distinct procedures and properties: FastRNA ${ }^{\circledR}$ Pro Blue (MPBiomedicals, Irvine, CA, US) uses mechanical and chemical lysis 
together with organic extraction; PureZOL ${ }^{\mathrm{TM}}$ RNA isolation reagent (Bio-Rad, Hercules, CA, US) uses chemical lysis with organic extraction, while PureLink ${ }^{\mathrm{TM}}$ RNA Mini Kit (Invitrogen, San Diego, CA, US) uses enzymatic lysis and silica membrane extraction.

\section{Methods}

\section{Bacteria and growth conditions}

S. epidermidis biofilms from two S. epidermidis strains with different genetic backgrounds (1457 [14] and M187 [15]) were individually used to form separate biofilms. Strains were individually propagated by inoculating a single colony in $2 \mathrm{~mL}$ Tryptic Soy Broth (TSB) (Oxoid, Cambridge, UK) from plates not older than 2 days and grown at $37^{\circ} \mathrm{C}$ in a shaker rotator at $120 \mathrm{rpm}$ for $24( \pm$ 2) hours. Then, $10 \mu \mathrm{L}$ of cell suspension was transferred to $2 \mathrm{~mL}$ of fresh TSB supplemented with $1 \%(\mathrm{w} / \mathrm{v})$ of glucose to induce biofilm formation in a 24-well plate (Orange Scientific, Braine-L'Alleud, Belgium). The plate was incubated at $37^{\circ} \mathrm{C}$ with shaking at $100 \mathrm{rpm}$ for 24 $( \pm 2)$ hours. Prior to total RNA extraction, the culture media was removed and the biofilm was washed with 1 $\mathrm{mL}$ of $\mathrm{NaCl} 0.9 \%$ solution to remove planktonic cells. In order to count the total viable cells (CFUs/mL) within each $S$. epidermidis biofilm, the biofilms were resuspended in $1 \mathrm{~mL}$ of $\mathrm{NaCl} 0.9 \%$ solution and sonicated on ice for $10 \mathrm{~s}$ at $30 \mathrm{~W}$. This procedure eliminates bacterial aggregates that do interfere with the CFUs counting [16]. Subsequently, 10 -fold dilutions in $0.9 \% \mathrm{NaCl}$ were performed and plated on Tryptic Soy Agar (Oxoid) plates. The plates were then incubated at $37^{\circ} \mathrm{C}$ overnight.

\section{Biofilm matrix composition}

Biofilm total biomass, protein, and polysaccharide matrix content was determined as described previously [17]. Briefly, the biofilm suspension was sonicated for 30 $\mathrm{S}$ at $30 \mathrm{~W}$ and, subsequently, centrifuged at $10.500 \mathrm{~g}$ for $6 \mathrm{~min}$ at $4^{\circ} \mathrm{C}$. This procedure did not reduced cell viability as determined by CFU counting [16]. The supernatants were then filtered through a $0.2 \mu \mathrm{m}$ nitrocellulose filter and the proteins and polysaccharide content determined by Bicinchoninic Acid (BCA) protein assay [17] (G-Biosciences, MO, US) and Dubois method [18], respectively. The total biomass of the biofilms was determined by optical density at $595 \mathrm{~nm}$. This experiment was performed in triplicates.

\section{RNA extraction and quality indicators}

Total RNA was isolated according the manufacturer's instructions, with the following modification, when appropriate: cell lysis was performed using $15 \mathrm{mg} / \mathrm{mL}$ of lysozyme for $60 \mathrm{~min}$ at $37^{\circ} \mathrm{C}$ with. This optimization increased the yield of total RNA 2-4-fold (data not shown). The final total RNA fraction was obtained by eluting or suspending the RNA in $45 \mu \mathrm{L}$ of DEPC-treated water. To digest contaminating DNA, DNase (Fermentas, Burlington, Ontario, Canada) treatment was performed by adding $5 \mu \mathrm{L}(10 \times)$ of reaction buffer with $\mathrm{MgCl}_{2}$ and $2 \mu \mathrm{L}$ DNase I to the extracted RNA and incubating the mixture at $37^{\circ} \mathrm{C}$ for $30 \mathrm{~min}$. Subsequently, $5 \mu \mathrm{L}$ of $25 \mathrm{mM}$ EDTA was added and incubated at $65^{\circ} \mathrm{C}$ for $10 \mathrm{~min}$ to inactivate the DNase I. Each experiment was performed in triplicates. The concentration and purity of the total RNA was spectrometrically assessed using a NanoDrop 1000 ${ }^{\mathrm{TM}}$ (Thermo Scientific, Waltham, MA, US). The absorbance ratios $\mathrm{A}_{260} / \mathrm{A}_{280}$ were used as indicators of protein contamination and $\mathrm{A}_{260} / \mathrm{A}_{230}$ as indicators of polysaccharide, phenol, and/ or chaotropic salts contamination [19]. The integrity of the total RNA was assessed by visualization of the 23S/ $16 \mathrm{~S}$ banding pattern. Electrophoresis was carried-out at $80 \mathrm{~V}$ for 60 min using a 1\% agarose gel. The gel was stained with ethidium bromide and visualized using a GelDoc2000 (Bio-Rad). Total RNA extractions were performed two to four times.

\section{Real time PCR (qPCR)}

To determine if the extracted RNA was functional, 40 ng of total RNA was reverse transcribed using an iScript $^{\mathrm{TM}}$ cDNA Synthesis Kit (Bio-Rad) following the manufacturer's instructions. Real time PCR (qPCR) was performed to quantify the mRNA transcripts. Primers (Invitrogen), specific for $16 \mathrm{~S}$ rRNA, reference gene, and icaA, a well-known virulence gene of $S$. epidermidis were designed using the Primer3 software [20] (Table 1). The experiment was performed using CFX96 ${ }^{\mathrm{TM}}$ thermocycler (Bio-Rad) with the following cycling parameters: $30 \mathrm{~s}$ at $94^{\circ} \mathrm{C}$ followed by 40 repeats of $5 \mathrm{~s}$ at $94^{\circ}$ C, $10 \mathrm{~s}$ at $60^{\circ} \mathrm{C}$, and finally $15 \mathrm{~s}$ at $72^{\circ} \mathrm{C}$, using Sso Fast $^{\mathrm{TM}}$ Evagreen Supermix $2 \times$ mix (Bio-Rad). Primers efficiency was determined by the dilution method as well as performing a temperature gradient reaction from 50 to $65^{\circ} \mathrm{C}$. At $60^{\circ} \mathrm{C}$, both set of primers had the best and more similar efficiencies (98 $\pm 4 \%$ for icaA and 95 $\pm 7 \%$ for $16 \mathrm{~S} r R N A$ ). To ensure the absence of genomic DNA contamination, a negative control was included in the reverse transcriptase reaction. The cycle threshold detection of each gene was determined using the

Table 1 Primers used in CDNA synthesis and amplification by qPCR

\begin{tabular}{ccc}
\hline Target gene & & Primers sequence $\left(\mathbf{5}^{\prime}\right.$ to $\left.\mathbf{3}^{\prime}\right)$ \\
\hline \multirow{2}{*}{$\mathbf{1 6 S}$} & $\mathrm{FW}$ & GGGCTACACACGTGCTACAA \\
\cline { 2 - 3 } & $\mathrm{RV}$ & GTACAAGACCCGGGAACGTA \\
\hline \multirow{2}{*}{$\boldsymbol{R} \boldsymbol{A} \boldsymbol{A}$} & $\mathrm{FW}$ & TGCACTCAATGAGGGAATCA \\
\cline { 2 - 3 } & $\mathrm{RV}$ & TAACTGCGCCTAATTTGGATT \\
\hline
\end{tabular}


standards parameters of the software. The melting curves were evaluated to ensure the absence of unspecific products and primer dimer formation. The expression of icaA was determined by using the delta $\mathrm{Ct}$ method $\left(2^{\Delta \mathrm{Ct}}\right)$, a variation of the Livak method, where $\Delta \mathrm{Ct}=\mathrm{Ct}$ (reference gene)-Ct (target gene). The data analysis was based on two to four independent experiments.

\section{Statistical analysis}

Statistical significance of results was determined by unpaired $t$ test using the Analysis Toolpak of Microsoft Excel 2007. $P<0.05$ was considered to be statistically significant.

\section{Results and Discussion}

The success of any RNA-based analysis depends on the quantity, purity, and integrity of the RNA [4,5]. RNA quality is influenced by the sample's nature and by the principle of the RNA extraction kit used. Thus, our objective was to test the performance of three different commercially available RNA extraction kits when using S. epidermidis biofilms as a sample. Regarding the total RNA yield obtained by the different kits, FastRNA ${ }^{\circledR}$ Pro Blue is clearly the kit with higher performance for both $S$. epidermidis strains $(P<0.01$ unpaired $t$-test) (Table 2 ). Comparing the RNA purity, FastRNA ${ }^{\circledR}$ Pro Blue was, again, the kit that extracted RNA with the highest purity. While most of the kits/strain combination produced total RNA with no protein contamination $\left(\mathrm{A}_{260} / \mathrm{A}_{280}\right)$, the only kit with a polysaccharides level $\left(A_{260} / A_{230}\right)$ above 1.8 was FastRNA ${ }^{\circledR}$ Pro Blue $(P<0.01$ unpaired $t$ test). Interestingly, significant differences were found in the total RNA quantity of the two strains of S. epidermidis used: while using FastRNA ${ }^{\circledR}$ Pro Blue strain 1457 yielded more RNA than strain M187, the opposite occurred in all the remaining kits. These differences are probably related with the strain specific ability to form biofilm and also with the composition of the biofilm matrix (Figure 1). These strains were selected from a

Table 2 Comparison of the RNA yield and purity obtained by the three RNA extraction kits

\begin{tabular}{|c|c|c|c|c|}
\hline $\begin{array}{c}\text { Extraction } \\
\text { kit }\end{array}$ & Strain & $\begin{array}{l}\text { RNA yield (ng/ } \\
\mu \mathrm{l})\end{array}$ & $\begin{array}{c}A_{260} / A_{280} \\
\text { ratio }\end{array}$ & $\begin{array}{c}A_{260} / A_{230} \\
\text { ratio }\end{array}$ \\
\hline \multirow[t]{2}{*}{ FastRNA $^{\circledR}$} & 1457 & $513 \pm 135^{* *}$ & $2.18 \pm 0.06$ & $2.06 \pm 0.01^{* *}$ \\
\hline & M187 & $359 \pm 14^{* *}$ & $2.09 \pm 0.04$ & $1.92 \pm 0.06 * *$ \\
\hline \multirow[t]{2}{*}{ PureZOL ${ }^{\mathrm{TM}}$} & 1457 & $18 \pm 7$ & $1.70 \pm 0.06$ & $0.30 \pm 0.01$ \\
\hline & M187 & $50 \pm 7 *$ & $1.70 \pm 0.07$ & $0.63 \pm 0.16$ \\
\hline \multirow[t]{2}{*}{ PureLink ${ }^{\mathrm{TM}}$} & 1457 & $17 \pm 3$ & $1.99 \pm 0.08$ & $1.35 \pm 0.04$ \\
\hline & M187 & $30 \pm 3^{*}$ & $2.10 \pm 0.06$ & $1.25 \pm 0.63$ \\
\hline
\end{tabular}

The values represent the mean plus or minus standard deviation of 2 to 4 independent experiments ( ${ }^{* *} P<0.01$ between kits; ${ }^{*} P<0.05$ between strains)



Figure 1 Quantification of biofilm formation and matrix composition. The biofilm forming capacity and protein and polysaccharide content in the biofilm matrix of each S. epidermidis strain. The optical density (OD $595 \mathrm{~nm}$ ) indicates the biofilm-

forming capacity of each S. epidermidis strain. The bars and the dot represent the mean plus or minus standard deviation of three independent experiments ( ${ }^{*} P<0.01$ between strains).

collection previously characterized for biofilm formation [21]: strain 1457 is a strong biofilm producer, while strain M187 is a moderate biofilm producer. When the biofilm matrices were extracted and analyzed, strain 1457 presented a significantly higher protein $(P<0.01$ unpaired $t$-test $)$ and polysaccharide $(P<0.05$ unpaired $t$-test) content than strain M187. As strain 1457 had a thicker biofilm, it seems reasonable to assume that the total number of cells available per biofilm would be higher, even taking in consideration that the majority of biofilm is composed of matrix and not bacteria [11]. We have confirmed this by resuspending the biofilms in $0.9 \% \mathrm{NaCl}$, performed dilutions and plating in TSA. While biofilms from strain 1457 contained $4.2 \times 10^{9}$ $\mathrm{CFU} / \mathrm{mL}$, strain $\mathrm{M} 187$ had $6.3 \times 10^{8} \mathrm{CFU} / \mathrm{mL}$. Thus, the initial amount of bacterial cells used for the RNA extraction seams to influence the total RNA quantity, as also described in the manufacturer guidelines. However, the relationship between the amount of sample and the RNA yield is not linear and each kit normally has an optimal range of sample concentration (PureLink ${ }^{\mathrm{TM}}$ - up to $1 \times 10^{9}$ bacteria, PureZOL ${ }^{\mathrm{TM}}$ - up to $2.4 \times 10^{9}$ bacteria, FastRNA ${ }^{\circledR}$ Pro Blue- up to $1 \times 10^{9}$ bacteria). Nour et al. [6] extracted RNA from rabbit blood samples using different extraction kits and determined that in one of the extraction kits used, too much concentrated sample would result in lower yield. However, in the majority of the cases reported, a lower initial sample concentration, yields lower amounts of RNA [6]. In the specific case of biofilms, higher cell densities will also mean higher external protein and polysaccharide contents, as confirmed herein (Figure 1). The presence of the biofilm matrix did not interfere in the extraction process of FastRNA ${ }^{\circledR}$ Pro Blue while in the remaining kits this was not the case. Interestingly, with strain 
M187, where the matrix presented lower levels of protein and polysaccharides, PureZOL ${ }^{\mathrm{TM}}$ and PureLink ${ }^{\mathrm{TM}}$ were more efficient as compared with strain 1457. Since FastRNA ${ }^{\circledR}$ Pro Blue was the only kit using mechanical lysis and had the highest RNA extraction performance, we tried to perform RNA extraction with PureZOL ${ }^{\mathrm{TM}}$ and PureLink ${ }^{\mathrm{TM}}$ preceded with the mechanical lysis step present on FastRNA ${ }^{\circledR}$ Pro Blue. Therefore, each biofilm was resuspended in the lysis buffer of the respective kit, but the lysis was completed mechanically following FastRNA ${ }^{\circledR}$ Pro Blue instructions. Interestingly, this modification did not significantly increased the RNA yield $(P>$ 0.10 unpaired $t$-test) (data not show). This suggests that the high RNA yield obtained with FastRNA ${ }^{\circledR}$ Pro Blue depends not only on the mechanical lysis, but also on the chemistry. The buffer used for FastRNA ${ }^{\circledR}$ Pro Blue lysis procedure contains phenol which is known to induce cell lysis [22], thus yielding more RNA than the other kits, which only used beads.

Besides the yield and purity, the extracted RNA should be intact and functional, in order to proper analyze the quantification of gene expression [4]. RNA integrity was assessed by agarose gel electrophoresis as reported above, and the expected double banding pattern of the $23 \mathrm{~S} / 16 \mathrm{~S}$ and the absence of a smear indicated the good integrity of RNA extracted (data not shown).

A previous study regarding the optimization of complementary DNA (cDNA) synthesis using commercially available kits, showed that in order to obtain reliable mRNA quantification at least $40 \mathrm{ng}$ of total RNA is necessary [23]. Thus, for cDNA synthesis and subsequent qPCR analysis we have normalized the concentration of total RNA obtained by the different kits to 40 ng. The qPCR results presented in Table 3 clearly show differences between each RNA extraction kit. Since $16 \mathrm{~S}$ rRNA is more abundant and stable, qPCR results will be highly influenced by the detection of specific mRNAs. This is of the upmost importance when using RNA for high throughput analysis, such as microarrays. Interestingly, the expression levels of icaA were significantly

Table 3 icaA expression values using RNA extracted from the three different kits

\begin{tabular}{ccccc}
\hline Extraction kit & Strain & 16S rRNA Ct & icaA Ct & icaA expression \\
\hline FastRNA $^{\circledR}$ & 1457 & $17.36 \pm 0.41$ & $31.48 \pm 0.28$ & $5.62 \times 10^{-5}$ \\
\cline { 2 - 5 } & M187 & $12.27 \pm 0.81$ & $27.07 \pm 1.05$ & $3.48 \times 10^{-5}$ \\
\hline PureZOL $^{\mathrm{TM}}$ & 1457 & $17.99 \pm 0.30$ & $31.84 \pm 0.11$ & $6.77 \times 10^{-5}$ \\
\cline { 2 - 5 } & M187 & $15.71 \pm 0.83$ & $29.58 \pm 1.94$ & $6.20 \times 10^{-5}$ \\
\hline PureLinkTM & 1457 & $15.25 \pm 0.12$ & $32.56 \pm 0.11$ & $0.62 \times 10^{-5} * *$ \\
\cline { 2 - 5 } & M187 & $13.83 \pm 0.67$ & $31.13 \pm 4.02$ & $0.62 \times 10^{-5} * *$ \\
\hline
\end{tabular}

Total RNA (40 ng) was used to synthesize cDNA for qPCR. The icaA expression was calculated by the delta $\mathrm{Ct}$ method $\left(2^{\Delta \mathrm{Ct}}\right)$. The values represent the mean plus or minus standard deviation of 2 to 4 independent experiments ( ${ }^{* *} P<$ 0.01). lower $(P<0.01$ unpaired $t$-test $)$ when using the RNA obtained from the PureLink ${ }^{\mathrm{TM}}$. This significant difference elucidates the importance of selecting the proper RNA extraction kit for the biological system being studied. It has been point-out that qPCR requires low amounts of total RNA, as when compared with microarrays [24]. However, the results reported here suggest that while qPCR can detect the expression of genes, independent of the quality and yield of RNA, the biological significance of the determined expression can be somewhat impaired. When trying to detect low expressing genes, a reduced RNA yield of extraction could place some low expressing genes below the limit of detection. While this was not the case with any of the kits tested in this study, however it can be inferred by the expression levels, that the kits with a lower total RNA yield were less efficient in recuperating mRNA.

\section{Conclusions}

Observing the overall results it can be seen that depending on the RNA extraction kit used, the quantification of mRNA transcripts can be impaired. Interestingly, of all the parameters tested, RNA purity seemed to have a lower impact in inhibiting RNA quantification. The $A_{260 / 280}$ and $A_{260 / 230}$ ratios are just indicators of possible contaminants in the RNA sample. While some of the contaminants can interfere in the downstream applications, it seems that more than the concentration of contaminants, the nature of contaminants will impair RNA quantification. FastRNA ${ }^{\circledR}$ Pro Blue showed the best results, while PureLink ${ }^{\mathrm{TM}}$ RNA mini kit was the worst kit for $S$. epidermidis biofilm samples.

When working with complex samples, such as biofilms, that contain a high content extracellular polysaccharide and proteins, special care should be taken when selecting the appropriate RNA extraction system, in order to obtain accurate, reproducible, and biologically significant results. Testing different systems and probing for well described gene expression conditions might elucidate some less apparent pitfalls of RNA extraction kits.

List of Abbreviations

BCA: Bicinchoninic Acid; cDNA: complementary DNA; CFU: Colony-forming unit: Ct: cycle threshold; mRNA: messenger RNA; OD: optical density: qPCR: Real time PCR; TSB: Tryptic Soy Broth.

\section{Acknowledgements}

This work was funded by European Union funds (FEDER/COMPETE) and by Portuguese national funds (FCT) under the projects with reference FCOMP01-0124-FEDER-014309 (PTDC/BIA-MIC/113450/2009). AF and LDRM

acknowledge the financial support of individual grants SFRH/BD/62359/2009 and SFRH/BD/66166/2009, respectively.

\section{Authors' contributions}

AF carried-out all of the RNA related experiments and drafted the manuscript. LDRM performed the biofilm formation and characterization analysis and aided in drafting the manuscript. NC conceived the study, 
participated in its design and coordination, and aided in drafting the manuscript. All authors read and approved the final manuscript.

\section{Competing interests}

The authors declare that they have no competing interests.

Received: 20 October 2011 Accepted: 30 December 2011 Published: 30 December 2011

\section{References}

1. Ziebuhr W, Hennig S, Eckart M, Kranzler H, Batzilla C, Kozitskaya S: Nosocomial infections by Staphylococcus epidermidis: how a commensal bacterium turns into a pathogen. Int J Antimicrob Agents 2006, 28(Suppl 1):S14-S20.

2. Vuong C, Otto M: Staphylococcus epidermidis infections. Microbes Infect 2002, 4:481-489.

3. Gotz F: Staphylococcus and biofilms. Mol Microbiol 2002, 43:1367-1378.

4. Bustin SA, Benes V, Nolan T, Pfaffl MW: Quantitative real-time RT-PCR-a perspective. J Mol Endocrinol 2005, 34:597-601.

5. Nolan T, Hands RE, Bustin SA: Quantification of mRNA using real-time RTPCR. Nat Protoc 2006, 1:1559-1582.

6. Nour AM, Barbour EK, Depint F, Dooms M, Niang K, Dulac A, Niamba CN, Chaaya G, Pouillart PR: Comparison of five RNA extraction methods from rabbit's blood. Agriculture and Biology Journal of North America 2010, 1:448-450.

7. Rump LV, Asamoah B, Gonzalez-Escalona N: Comparison of commercial RNA extraction kits for preparation of DNA-free total RNA from Salmonella cells. BMC Res Notes 2010, 3:211.

8. Cury JA, Koo H: Extraction and purification of total RNA from Streptococcus mutans biofilms. Anal Biochem 2 007, 365:208-214.

9. Cury JA, Seils J, Koo H: Isolation and purification of total RNA from Streptococcus mutans in suspension cultures and biofilm. Braz Oral Res 2008, 22:216-222.

10. Perez-Osorio AC, Franklin MJ: Isolation of RNA and DNA from biofilm samples obtained by laser capture microdissection microscopy. CSH Protoc 2008, 2008, pdb.prot5065.

11. Flemming HC, Wingender J: The biofilm matrix. Nature 2010, 8:623-633.

12. Junttila S, Lim KJ, Rudd S: Optimization and comparison of different methods for RNA isolation for cDNA library construction from the reindeer lichen Cladonia rangiferina. BMC Res Notes 2009, 2:204.

13. Santiago-Vázquez LZ: Comparison of two total RNA extraction protocols using the marine gorgonian coral Pseudopterogorgia elisabethae and its symbiont Symbiodinium sp. Electronic Journal of Biotechnology 2006, 9:598-603.

14. Mack D, Nedelmann M, Krokotsch A, Schwarzkopf A, Heesemann J, Laufs R: Characterization of transposon mutants of biofilm-producing Staphylococcus epidermidis impaired in the accumulative phase of biofilm production: genetic identification of a hexosamine-containing polysaccharide intercellular adhesin. Infect Immun 1994, 62:3244-3253.

15. Muller E, Hubner J, Gutierrez N, Takeda S, Goldmann DA, Pier GB: Isolation and characterization of transposon mutants of Staphylococcus epidermidis deficient in capsular polysaccharide/adhesin and slime. Infect Immun 1993, 61:551-558.

16. Cerca F, Andrade F, Franca A, Andrade EB, Ribeiro A, Almeida AA, Cerca N, Pier G, Azeredo J, Vilanova M: Staphylococcus epidermidis biofilms with higher proportions of dormant bacteria induce a lower activation of murine macrophages. J Med Microbiol 2011, 60:1717-1724.

17. Cerca N, Martins S, Sillankorva S, Jefferson KK, Pier GB, Oliveira R, Azeredo J: Effects of growth in the presence of subinhibitory concentrations of dicloxacillin on Staphylococcus epidermidis and Staphylococcus haemolyticus biofilms. Appl Environ Microbiol 2005, 71:8677-8682.

18. Dubois M, Gilles K, Hamilton J, Rebers P, Smith F: Colorimetric method for determination of sugars and related substances. Anal Chem 1956, 28:350-356.

19. Tavares $L$, Alves PM, Ferreira RB, Santos CN: Comparison of different methods for DNA-free RNA isolation from SK-N-MC neuroblastoma. BMC Res Notes 2011, 1:140.

20. Rozen S, Skaletsky H: Primer3 on the WWW for general users and for biologist programmers. In Methods in Molecular Biology. Edited by: Krawetz S, Misenser S. Totowa, NJ. Humana Press; 2000:365-386.
21. Cerca N, Pier GB, Vilanova M, Oliveira R, Azeredo J: Quantitative analysis of adhesion and biofilm formation on hydrophilic and hydrophobic surfaces of clinical isolates of Staphylococcus epidermidis. Res Microbiol 2005, 156:506-514.

22. Pulvertaft RJ, Lumb GD: Bacterial lysis and antiseptics. J Hyg (Lond) 1948, 46:62-64.

23. Sieber MW, Recknagel P, Glaser F, Witte OW, Bauer M, Claus RA, Frahm C: Substantial performance discrepancies among commercially available kits for reverse transcription quantitative polymerase chain reaction: a systematic comparative investigator-driven approach. Anal Biochem 2010, 401:303-311.

24. Wong ML, Medrano JF: Real-time PCR for mRNA quantitation. Biotechniques 2005, 39:75-85.

doi:10.1186/1756-0500-4-572

Cite this article as: França et al.: Comparison of RNA extraction methods from biofilm samples of Staphylococcus epidermidis. BMC Research Notes $20114: 572$

\section{Submit your next manuscript to BioMed Central and take full advantage of:}

- Convenient online submission

- Thorough peer review

- No space constraints or color figure charges

- Immediate publication on acceptance

- Inclusion in PubMed, CAS, Scopus and Google Scholar

- Research which is freely available for redistribution

Submit your manuscript at www.biomedcentral.com/submit
Biomed Central 